\title{
Os ECONOMistas-COLUNISTAS NO DEBATE SOBRE AS REFORMAS NO BRASIL ${ }^{11}$
}

\author{
Allana Meirelles VIEIRA* \\ Aline Rodrigues CHIARAMONTE**
}

\begin{abstract}
RESUMO: Esta pesquisa analisou a dinâmica estabelecida entre as posições dos economistas-colunistas no campo do poder e suas tomadas de posição acerca da PEC 241 e das reformas da Previdência e a Trabalhista. Para tanto, adotamos como objeto os colunistas economistas dos principais jornais generalistas do país - Folha de S.Paulo, $O$ Estado de S. Paulo e $O$ Globo. Delineando suas posições em relação aos poderes econômico e político assim como ao campo acadêmico e à mídia e analisando os discursos proferidos acerca das reformas, foi possível compreender as trocas simbólicas que esses agentes estabelecem entre si bem como com os jornais em que escrevem. Sublinhamos, ainda, a importância desses agentes para a ratificação e reiteração de determinados projetos para o país, como difusores de uma doxa forjada em lugares nos quais agentes provenientes de diferentes campos sociais estabelecem trocas.
\end{abstract}

PALAVRAS-CHAVE: Economistas. Jornalismo. Campo do poder. Reformas.

Desde o início do processo de impeachment da presidenta Dilma Rousseff, em 2016, e sua substituição pelo então vice-presidente, Michel Temer, o tema das reformas - incluindo a Trabalhista e a da Previdência - foi intensificado em debates nos principais veículos de comunicação do Brasil. Como uma reverberação da polarização política observada desde as eleições presidenciais de 2014, esses debates se colocam como marcadores interessantes para a compreensão das tomadas de

\footnotetext{
11 Uma primeira versão deste artigo foi apresentada no $42^{\circ}$ Encontro Anual da Anpocs.

* USP - Universidade de São Paulo. Programa de Pós-Graduação em Sociologia. São Paulo - SP - Brasil. 05508-010 - allanameirelles@usp.br. https://orcid.org/0000-0001-9925-8965.

** USP - Universidade de São Paulo. Programa de Pós-Graduação em Sociologia. São Paulo - SP - Brasil. 05508-010 - aline.chiaramonte@usp.br. https://orcid.org/0000-0002-7629-8072.
} 
posição de figuras e instituições públicas. Nesse contexto político, marcado por crises $^{12}$ e fortes oposições, professores, jornalistas, escritores, artistas, militantes, políticos, movimentos sociais, organizações e partidos foram levados a se manifestar, seja a favor ou contra as reformas e, consequentemente, ao governo de Michel Temer $^{13}$.

Dentre as figuras que se engajaram nesse debate público, destacou-se a participação dos economistas, frequentemente convidados em programas televisivos de debate, solicitados a dar explicações e soluções para os problemas do país, assim como periodicamente presentes em colunas de jornais e revistas. Elevados à condição de especialistas, esses atores têm tido papel crescente no enquadramento dos problemas sociais, na formulação e na difusão de propostas para solucioná-los assim como ocupam cargos burocráticos e de assessoria política (LOUREIRO, 2006).

Foi entre os anos de 1940 e 1970 que os economistas se tornaram importantes integrantes da elite dirigente do país, assumindo postos de importância no Estado brasileiro, antes ocupados por bacharéis, políticos e homens de negócios. Essa crescente participação acompanhava a implementação dos cursos de pós-graduação na área e os incentivos dados aos estudantes e professores para o doutoramento no exterior (LOUREIRO, 2006).

A atuação dos economistas se ampliou, inclusive, para outras esferas, como a educação. Segundo Almeida (2008), é a partir dos anos 1970 que esses experts, como detentores de instrumentos econométricos, conhecimentos técnicos e diplomas de prestígio, buscam valorizar seus capitais nos espaços de produção de políticas públicas para a educação, influenciando-as. Indo em direção semelhante, Carlotto (2014) aborda a visão da ciência enquanto uma atividade econômica por parte desses profissionais, levando à utilização de um ferramental estatístico para mensurar investimentos e retornos, moldando assim os rumos da ciência no país.

Klüger (2017) mapeia três gerações de economistas brasileiros (entre o final dos anos 1930 e o início dos 2000), apresentando as propriedades diferenciais que caracterizam os agentes em cada uma delas, ao mesmo tempo em que sublinha a existência de disposições sociais comuns àqueles que apostaram na profissão,

\footnotetext{
12 As crises econômica e política são anunciadas por diferentes periódicos: O Brasil além da crise (FUCS, 2017); Brasil enfrenta pior crise já registrada poucos anos após um boom econômico (TREVIZAN, 2017); A crise política e o desânimo do povo com seus representantes (CARTA CAPITAL, 2017); Brasil, um gigante abatido (HERMIDA, 2018).

13 Os momentos de crise levam os agentes sociais a fazerem escolhas e proclamarem-nas, de modo que as situações nas quais não escolher é também uma escolha se multiplicam. Assim, constrói-se uma problemática política comum, um espaço de tomadas de posição constituídas, no qual as pessoas não podem evitar situar-se ou serem situadas (BOURDIEU, 1984, p.235).
} 
ajudando a desenvolvê-la e a criar a crença na sua importância - são elas: "a perspectiva missionária, a adaptabilidade e a multiposicionalidade" (KLÜGER, 2017, p.787). Esse trabalho permite um conhecimento detalhado do espaço dos economistas, das suas disposições e dos laços que os unem - de parentesco e amizade, criados durante a passagem pelas mesmas instituições escolares e profissionais. A autora sublinha, dentre outras coisas, a importância da experiência dos economistas no Estado, no setor privado e na academia como meio desses agentes concentrarem poder simbólico, impondo suas falas como legítimas tanto no setor público quanto no privado (KLÜGER, 2017).

O presente artigo, ao ter como objeto os economistas-colunistas, busca incluir na análise a atuação midiática, mais especificamente no jornalismo impresso. Aspira, desse modo, captar as relações de troca estabelecidas entre economistas e diários, de forma a apontar os ganhos simbólicos que tais relações podem trazer para ambos, mormente para seus posicionamentos em questões prementes no campo do poder.

Assim, ele tem como objeto de investigação colunistas de economia, especificamente economistas, dos principais jornais generalistas do país - Folha de S.Paulo, O Estado de S. Paulo ${ }^{14}$ e $O$ Globo, no período 2016-2018. Estudamos essas figuras a partir da análise entre a dinâmica de suas posições - as relações que estabelecem com outros poderes (econômicos, políticos, acadêmicos) e no interior do espaço midiático - e as respectivas tomadas de posição sobre a Reforma da Previdência e a Trabalhista assim como sobre a Proposta de Emenda Constitucional PEC $241^{15}$. Dessa forma, buscamos dar inteligibilidade sociológica para os posicionamentos adotados por esses colunistas.

Para tanto, a pesquisa foi realizada seguindo as etapas: 1) levantamento dos colunistas economistas que se posicionaram sobre as reformas nos três jornais apontados; 2) investigação de suas trajetórias profissionais e políticas, a partir de seus currículos disponibilizados em páginas pessoais de redes sociais, currículos online (Lattes e LinkedIn), descrições nos sites para os quais escrevem e biografias no Centro de Pesquisa e Documentação de História Contemporânea do Brasil (CPDOC). O objetivo foi levantar os veículos de comunicação em que trabalham, a atuação em cargos públicos e políticos, a experiência no setor privado e em agências de consultoria bem como a relação com partidos; 3) análise dos textos que escreveram sobre a PEC e as reformas entre 2014 e 2018. O conteúdo foi acessado nos sites dos jornais, depositórios de suas colunas. Por meio da análise da opinião explicitada (com

\footnotetext{
${ }^{14} \mathrm{O}$ jornal $O$ Estado de São Paulo também se denomina Estadão.

15 PEC 241, PEC 55, PEC do teto de gastos ou PEC 95, Proposta de Emenda Constitucional que cria um teto para os gastos públicos.
} 
o foco nas razões elencadas para a defesa ou não das reformas e na montagem da argumentação para a sustentação das posições), das estratégias discursivas empregadas e dos exemplos utilizados, a intenção foi reconstruir as tomadas de posição dos dois polos que se formaram em torno do debate; 4) esboço do posicionamento desses economistas nos campos do poder e jornalístico a partir dos dados coletados nas etapas anteriores.

\section{O jornalismo econômico no Brasil}

Os principais jornais do país - Folha de S.Paulo, O Estado de S. Paulo e $O$ Globo - apresentam em suas páginas impressas e online um conjunto de colunistas de política e economia dedicados a construir explicações sobre o país e o mundo assim como a apontar soluções para os problemas contemporâneos.

Desse conjunto, uma parcela tem se destacado nos últimos anos por sua formação em economia. Foi nas décadas de 1960 e 1970 que o jornalismo econômico tal como conhecemos começou a tomar forma (ABREU, 2003). Ainda que anteriormente os jornais tivessem o hábito de divulgar notícias ligadas à economia, especialmente ao mundo agrícola, foi nesse período que os jornais intensificaram a editoria, com a ampliação dos temas abordados e do espaço destinado aos assuntos relacionados.

O crescimento do jornalismo econômico nesse período é atribuído ao contexto de censura do regime militar, que levou os donos de jornais a substituir o noticiário político pelas informações econômicas e internacionais (ABREU, 2003), supostamente mais difíceis de serem censuradas. Isso porque os governos militares viriam menos risco nesse conteúdo, já que era voltado a um público mais específico. Além disso, segundo Abreu, alguns empresários do ramo midiático perceberam o contexto favorável à criação de periódicos especializados, "dirigidos a um público de tomadores de decisão, tecnocratas e formadores de opinião" (ABREU, 2003, p.26). Essas afirmações são baseadas em estudos que demonstram o aumento relativo das notícias de economia e internacional em relação às de política nacional (SCAVONE; BELLONI; GARBAYO, 1975 apud ABREU, 2003).

Se nos anos pós 1964, os jornalistas viviam um espírito de engajamento político e oposição ao regime militar, posteriormente, em 1990, essa postura se transformaria em posições desengajadas e atitudes mais apolíticas (ABREU, 2003). É certo que essa transformação se relaciona aos processos de modernização da imprensa ocorridos nas décadas anteriores nos diferentes jornais assim como com a disputa entre 
gerações diferentes de jornalistas - questões que têm sido temas de diversas pesquisas (RIBEIRO, 2003; BARBOSA, 2007; BERGAMO, 2011; CHIARAMONTE, 2015; MORAES, 2017).

A profissionalização do jornalismo - com a implementação de regimes de dedicação exclusiva e salários maiores, com a obrigatoriedade do diploma a partir de 1969 e a inserção de técnicas de apuração e redação herdeiras do modelo norteamericano de jornalismo - foi aos poucos modificando as dinâmicas internas das redações ${ }^{16}$. Esse processo ensejou, mais tarde, uma disputa entre os jornalistas antigos - que viveram a fase de engajamento político e de censura do regime militar assim como os períodos anteriores, mais românticos da imprensa, por sua proximidade com a literatura - e os novos profissionais - formados nas faculdades de jornalismo e inseridos na imprensa já em um momento de despolitização da figura do jornalista (BERGAMO, 2011; MORAES, 2017).

Apesar dessa disputa, os novos paradigmas profissionais influenciaram a todos dentro das redações. Os jornalistas econômicos, antes ligados a partidos de esquerda, como o Partido Comunista Brasileiro (PCB) ou o Partido Comunista do Brasil $(\mathrm{PCdoB})$ e a movimentos de inspiração marxista, tornaram-se mais distantes da postura militante - haja vista, figuras como Míriam Leitão. Porém, é preciso ressaltar que mesmo à época da ditadura, esses jornalistas tentavam conciliar a militância, a busca por determinada autonomia e a necessidade de garantir o emprego e as condições mínimas de trabalho, lidando, assim, de forma ambígua com a censura (ABREU, 2003).

Desde então, a relação entre jornalistas econômicos e suas fontes se construiu a partir de uma relativa dependência. Com a inserção intensificada da editoria de economia nos principais jornais do país assim como com o aumento de seu prestígio, os jornalistas tiveram que se adaptar a essa realidade, aprendendo sobre o assunto de forma quase que autodidata, a partir da relação com as próprias fontes. Os técnicos que atuavam em empresas públicas e privadas, os ministros da Fazenda, os economistas de instituições de pesquisa e ensino, e os empresários ofereciam não apenas informação e dados aos jornalistas, mas também explicações e lições sobre o tema, em almoços, entrevistas, seminários etc. (ABREU, ROCHA, 2006,).

Alzira Alves de Abreu (2003) explicita a relação de dois ministros da Fazenda do regime militar e a imprensa: Delfim Netto e Mario Henrique Simonsen. O primeiro

\footnotetext{
16 Duval (2004) aponta como o desenvolvimento do jornalismo defensor da economia liberal e dos grupos sociais bem providos de capital econômico e cultural está relacionado às transformações no mundo jornalístico, como a rotinização do profissionalismo e o desenvolvimento das práticas de marketing.
} 
controlava fortemente as informações governamentais disponibilizadas aos meios de comunicação:

Ele conversava pessoalmente com os editores de economia e exercia seu poder de 'economista brilhante' passando a imagem de que só conversava com jornalistas altamente qualificados. Tornava-se assim motivo de vaidade e orgulho profissional ser eleito para conversar com o ministro. Essa era uma das estratégias de manipulação utilizadas pelo poder (ABREU, 2003, p.29).

Por outro lado, Simonsen é retratado como oposto a Delfim Netto, já que permitia a contestação da política econômica assim como apreciava o debate, adotando uma postura de convencimento dos jornalistas. "Eu achava o máximo ter 'aula' com ele todos os dias", afirmou Lilian Witte Fibe (ABREU, 2003, p.51). Ainda que a respeitasse, Fibe afirmou que o ministro não gostava muito dela, pois era muito inquisidora, e que as autoridades não estavam acostumadas a isso. Da mesma forma, essa figura seria, posteriormente, a referência de Míriam Leitão. "Mas se você ligasse para ele e dissesse: 'Não estou entendendo o que está acontecendo', ele lhe dava uma aula brilhante", afirmou a jornalista em entrevista publicada no livro Elas ocuparam as redações (ABREU; ROCHA, 2006, p.90).

Ambos os relatos evidenciam a relação de dependência, medo e admiração entre jornalistas econômicos e suas fontes. Se, com a redemocratização, o medo da censura foi abolido, os outros dois sentimentos parecem ter permanecido. Apesar do prestígio e da relativa autonomia conquistados, os colunistas de economia dos jornais ainda possuíam dependência de um restrito número de fontes, nos anos 1990 situação que aparentemente se mantém, haja vista a repetição de determinados experts nas páginas dos principais jornais. Além disso, nos anos 1990, as empresas intensificaram suas assessorias de imprensa, dedicadas a aumentar a inserção de notícias positivas nos jornais, funcionando como lobbies e contralobbies: "Os empresários entenderam que precisam de uma comunicação competente com os centros de poder e decisão, com o Congresso e o público consumidor, o que os levou a investir na produção de informação" (ABREU, 2003, p.65).

Contemporaneamente, esse panorama do jornalismo econômico se apresenta de forma mais complexa. Uma busca preliminar nos acervos dos principais jornais do país - Folha de S.Paulo, O Estado de S. Paulo e $O$ Globo - demonstra que o número de citações da palavra economista cresceu vertiginosamente entre os anos 1960 e 2000. Na década de 1960, o jornal $O$ Globo fez menção à palavra 4.942 vezes, já nos 
anos 2000, esse número foi para 16.699 - ou seja, mais do que triplicou. O crescimento foi ainda mais intenso nos jornais paulistas: na Folha, as citações subiram de 2.534, nos anos 1960, para 18.320 - ou seja, intensificou-se 7 vezes mais; no $O$ Estado de S. Paulo, elas foram de 2.336 para 28.772 , em 50 anos -12 vezes mais ${ }^{17}$.

Mais do que isso, a relevância e o prestígio da editoria de economia dentro das redações jornalísticas também continuam crescendo. Alguns investimentos das empresas de comunicação ilustram essa afirmação. Em 1991, a Agência Estado pertencente ao grupo Estado e criada em 1970 - incorporou a empresa Broadcast, voltada para a produção de informações econômicas em tempo real. O sistema, então, tinha clientes como a Bradesco Corretora e o Unibanco (ESTADÃO, 1991). O Broadcast já era, antes da incorporação, um difusor que transmitia diversos serviços ao sistema financeiro, como cotações; sinopses de jornais e informações instantâneas dos bastidores do mercado, produzidas na época, por Luiz Nassif; gráficos comentados; e outras ferramentas úteis na decisão de qual ação comprar ou vender (ESTADÃO, 1988).

Mas foi nos anos 2000 que o serviço começou a se popularizar. Em 2006, a Agência Estado lançou o AE Broadcast Investidor Pessoal e o AE Móvel, com a proposta de alcançar também as pessoas físicas não profissionais (ESTADÃO, 2006). Em 2009, o Broadcast já era responsável por $80 \%$ da receita da Agência Estado (ESTADÃO, 2009), com 15 mil terminais pelo Brasil. Já em 2011, quando 98\% dos usuários do $A E$ Broadcast eram profissionais de instituições financeiras, o Grupo lançou o Estadão Broadcast, com notícias, análises, gráficos, cotações e outras ferramentas para investidores individuais, pequenos e médios (ESTADÃO, 2011). Conforme se verifica no site da empresa, ela conta atualmente com uma diversidade de produtos no ramo - o Broadcast Político, o Broadcast Agro, o Trading News, o Broadcast Web e o Broadcast Datafeed -, todos destinados a oferecer as informações estratégicas na decisão da compra ou venda de ações no mercado financeiro assim como das negociações do agronegócio (BROADCAST, 2018). Em 2013, o Valor Econômico - fruto de uma parceria entre o Grupo Folha e o Grupo Globo ${ }^{18}$ - também lançou sua plataforma de notícias financeiras em tempo real, o Valor PRO.

Esses novos produtos das empresas de comunicação modificaram, inclusive,

\footnotetext{
17 Para fins comparativos, buscando o termo "advogado", profissão que sempre teve espaço na imprensa brasileira, encontramos a seguinte evolução: O Globo - passou de 17.225 menções a 35.296, entre as décadas de 1960 e 2000; Folha - passou de 9.007 citações a 36.852, no mesmo período; Estadão - passou de 9.873 a 38.025.

18 Em 2016, o Grupo Globo comprou do Grupo Folha os 50\% do jornal Valor Econômico, passando a deter $100 \%$ da empresa $(\mathrm{G} 1,2016)$.
} 
as rotinas de produção e divulgação das notícias assim como as relações entre jornalistas e fontes (PULITI, 2009; UNDURRAGA, 2016). Undurraga (2016) demonstra, por exemplo, no caso do Valor Pro, como a convergência das redações levou à agudização de disputas já existentes entre jornalistas de diferentes rubricas, favorecendo também o florescimento de novas controvérsias políticas e profissionais. Além disso, ele ressalta que com a introdução do serviço a temática financeira se tornou mais importante nas redações.

Tratando-se de serviços em tempo real, com atualizações a cada segundo, eles contribuíram para estabelecer uma interlocução recorrente entre jornalistas e agentes do sistema financeiro assim como tornaram-se fonte de notícias para outros veículos (PEDROSO; UNDURRAGA, 2016; PULITI, 2009; UNDURRAGA, 2016). Além disso, o Broadcast - pioneiro no Brasil - também modificou a forma de relação entre governo, jornalistas e agentes do mercado, impondo uma lógica temporal mais imediata - levando o governo a dar respostas mais rápidas à imprensa e a utilizar esse espaço para acalmar investidores e operadores do mercado financeiro (PULITI, 2009).

Tais serviços contam com jornalistas com certo nível de especialização em economia (PULITI, 2009). Como indício do prestígio que a editoria vem ganhando e da consequente cobrança por especialização, em 2010, o Grupo Estado lançou o curso de Jornalismo Econômico - vulgarmente denominado como curso Focas -, voltado para jornalistas recém-formados ou estudantes do último ano da graduação em jornalismo. Em parceria com a Fundação Getúlio Vargas (FGV), o curso oferece aulas teóricas com os professores da instituição assim como treinamento nas diferentes plataformas jornalísticas da empresa: Agência Estado, Broadcast, sites e jornal impresso (ESTADÃO, 2012). Após os três meses de curso, os aproximadamente 25 trainees podem ser contratados para trabalhar nas redações, em especial, da Agência Estado, da qual faz parte o Broadcast.

No site do Valor Pro, a proposta da plataforma é colocada nos seguintes termos: "Completa cobertura em tempo real com notícias exclusivas, análises, furos e bastidores sobre economia, negócios, política, empresas, finanças, entre outros temas, produzidos por uma especializada equipe de jornalistas e economistas" (VALOR PRO, 2009, n.p.). Como Pedroso e Undurraga (2009) verificaram a partir de entrevistas realizadas com nomes da elite do jornalismo econômico, um dos princípios atuais de hierarquização desse tipo de jornalismo é a ideia de mexer com o mercado (PEDROSO; UNDURRAGA, 2009). Sendo assim, a publicação de notícias que dizem respeito às atividades financeiras seria privilegiada em manchetes assim como produziria certo prestígio para o profissional ou veículo de comunicação. Nesse sentido, é possível conjecturar que, hoje, a prioridade das empresas de comunicação 
em termos do furo e da informação exclusiva se destine mais a esses serviços pagos ${ }^{19}$ do que aos jornais impressos, tendo em vista esse princípio de hierarquização e a representatividade desses produtos nas receitas internas ${ }^{20}$ acompanhada da queda de assinaturas de jornais ${ }^{21}$.

Como Duval (2004) argumenta, o desenvolvimento do jornalismo econômico na França está atrelado ao crescimento do poder do pensamento econômico e liberal, de modo que essa editoria se configura como uma espécie de vanguarda do mundo jornalístico. A difusão de um vocabulário, mas, mais do que isso, de um modo de pensar típico do mundo econômico não teria, nesse contexto, apenas influenciado o discurso jornalístico, mas também outras esferas, como a política, a educação, a saúde, o esporte e a cultura, de modo que todos os domínios parecem impregnados pelo pensamento administrativo e pela lógica da gestão. No Brasil, Pedroso e Undurraga (2009) também verificaram o compartilhamento da doxa mainstream sobre o funcionamento da economia entre a elite do jornalismo econômico e os agentes eficientes do campo econômico - fruto dos vínculos que essas figuras estabelecem entre si e da possibilidade de realização da illusio profissional por parte dos jornalistas ao adotarem os princípios de visão de mundo dos agentes dominantes do campo econômico.

Nesse contexto, as colunas de economia ocupam um papel de prestígio, mas também estratégico economicamente, na imprensa brasileira. Esses espaços são ocupados por jornalistas de economia e por experts, ou seja, economistas com ampla formação acadêmica e experiências em diversos setores da economia e da política.

\section{Os economistas: os colunistas experts}

Dos colunistas que escrevem nos periódicos analisados neste trabalho, alguns são economistas, a maioria com doutorado em economia em instituições prestigiadas e internacionais, como Universidade de São Paulo (USP), Harvard, London School of

${ }^{19}$ Conforme informações obtidas com as vendedoras dos serviços em 2018, a mensalidade do Valor Pro era de R \$ 1.270,00 enquanto a do Broadcast voltado para pessoa física variava de $\mathrm{R} \$ 260,00$ a $\mathrm{R} \$ 1.500,00$, dependendo dos serviços adquiridos.

20 Em 2009, reportagem do jornal $O$ Estado de $S$. Paulo afirmou que o Broadcast já representava $80 \%$ da receita da Agência Estado (ESTADÃO, 2009, p. 4).

${ }^{21}$ Entre 2014 e 2017, a média anual de circulação impressa do Estadão caiu 51.212 pontos, do $O$ Globo diminuiu em 71.770, e da Folha, em 86.716, segundo dados fornecidos pelo Instituto Verificador de Comunicação (IVC). 
Economics (LSE) e New School for Social Research ${ }^{22}$. No Estadão, em 2018, havia seis economistas: Monica Baumgarten de Bolle, Gustavo Henrique de Barroso Franco, Affonso Celso Pastore, Claudio Adilson Gonçalez, José Roberto Mendonça de Barros e Zeina Latif. Na Folha de S.Paulo, eles também eram seis: Alexandre Schwartsman, Samuel Pessôa, Marcos Lisboa, Laura Carvalho, Nelson Barbosa, Delfim Netto. No jornal $O$ Globo, apenas um colunista era economista: Gustavo Franco, também articulista do Estadão $^{23}$. Os diplomas de prestígio se convertem, assim, em legitimidade na elaboração de análises conjunturais, críticas e sugestões às políticas implementadas no país. Com tal legitimidade, esses nomes não se restringem às suas próprias colunas, mas circulam como fontes dos três jornais bem como de canais de televisão, como a Globo News.

Se a extensa formação acadêmica os legitima a ocupar as páginas dos principais jornais do país, não é nesse espaço que eles constroem primordialmente suas carreiras, ao contrário do que ocorre, por exemplo, com os colunistas formados em jornalismo. Os doutores figuram, assim, como professores em instituições de ensino superior públicas e privadas do país, caracterizadas, especialmente, pela formação de uma elite do campo econômico. Gustavo Franco e Monica de Bolle foram professores da Pontifícia Universidade Católica do Rio de Janeiro (PUC-RJ). Samuel Pessôa, Affonso Celso Pastore e Nelson Barbosa atuam como docentes na Fundação Getúlio Vargas (FGV), por onde já passaram Marcos Lisboa e Laura Carvalho. Zeina Latif deu aulas no Master of Business Administration (MBA) do Instituto Brasileiro de Mercado de Capitais (IBMEC), instituição pela qual Pastore também já passou, e na Universidade Mackenzie. Alexandre Schwartsman passou pelo Instituto de Ensino e Pesquisa (Insper) e pela PUC-SP. No Insper, Marcos Lisboa é presidente. Na Universidade de São Paulo (USP), José Roberto Mendonça de Barros e Delfim Netto fizeram carreira, lecionando por mais de 30 anos - instituição na qual Laura Carvalho é docente atualmente. Nelson Barbosa ainda passou por universidades federais, como a Universidade de Brasília (UnB), a Universidade Federal do Rio de Janeiro (UFRJ) e a Universidade Federal Fluminense (UFF). Além disso, alguns nomes lecionaram em instituições estrangeiras: José Roberto Mendonça de Barros na Ohio State University, Marcos Lisboa na Stanford University, Nelson Barbosa na St. Francis College e na

\footnotetext{
22 O departamento de economia desta instituição se apresenta como um dos poucos programas de pósgraduação do mundo que enfatiza disciplinas como história econômica, economia política e história da economia, incluindo abordagens heterodoxas (THE NEW SCHOOL FOR SOCIAL RESEARCH, 2018).

${ }^{23}$ Privilegiamos o estudo das trajetórias e dos textos dos economistas que tecem análises acerca da conjuntura macroeconômica do país. Dentre eles, selecionamos todos os que são definidos como colunistas nos sites dos jornais, atuantes, pelo menos, de 2016 até 2018.
} 
New School for Social Research.

Além da academia, esses colunistas circulam também por posições de importância política bem como já ocuparam postos em bancos e instituições do sistema financeiro. Laura Carvalho ${ }^{24}$ é o único nome destoante, já que não assumiu nenhum cargo político e nem passou pelo setor privado, dedicando a carreira à universidade e às intervenções na imprensa.

Delfim Netto ocupou os principais cargos de política econômica durante o regime militar: Ministro da Fazenda (1967-1974), Embaixador do Brasil na França (1974-1978), Ministro da Agricultura (1979), Ministro do Planejamento (1979-1985), além de ter sido deputado federal (Constituinte: 1987-1991; 1991-2007). De maneira semelhante, Affonso Celso Pastore também alcançou postos de destaque durante a ditadura militar: foi o último presidente do Banco Central do regime (1983-1985), além de ter atuado como assessor do Ministério da Fazenda e do Planejamento, entre 1967 e 1973.

Na década de 1980, após a redemocratização, Carlos Adilson Gonçalez participou das equipes econômicas de Luiz Carlos Bresser-Pereira (1987) e Maílson da Nóbrega (1988-1990) no Ministério da Fazenda. Na década seguinte, Gustavo Franco chegou a postos de prestígio como presidente e diretor de assuntos internacionais do Banco Central e secretário adjunto de política econômica do Ministério da Fazenda (1993-1999). No mesmo período, José Roberto Mendonça de Barros foi secretário de política econômica do Ministério da Fazenda (1995-1998) e secretário-executivo da Câmara de Comércio Exterior da Presidência da República (1998).

Nos anos 2000 e 2010, quem integrou a equipe econômica dos governos foi Nelson Barbosa, como chefe adjunto da assessoria econômica do Ministério do Planejamento (2003); assessor da presidência do Banco Nacional de Desenvolvimento Econômico (BNDES) (2005-2006); secretário adjunto de política econômica (20062007), secretário de acompanhamento econômico (2007-2008), secretário de política econômica (2008-2010), secretário executivo (2011-2013) no Ministério da Fazenda; ministro do Planejamento (2014) e da Fazenda (2015); presidente do conselho de administração do Banco do Brasil (2009-2013). Além dele, Marcos Lisboa assumiu a secretaria de política econômica do Ministério da Fazenda, entre 2003 e 2005; e Alexandre Schwartsman foi diretor de assuntos internacionais do Banco Central, entre 2003 e 2006.

Quanto aos cargos no sistema financeiro e em instituições privadas, Barros foi

\footnotetext{
${ }^{24}$ Há que se ressaltar que Laura Carvalho é a mais nova dentre os economistas-colunistas, o que pode ser uma explicação para o fato de não ter acumulado experiências no setor público e privado, como os outros.
} 
membro do comitê estratégico da Vale do Rio Doce, integrante membro do conselho consultivo da Federação Brasileira de Bancos (FEBRABAN) e do conselho consultivo/administrativo do Banco Santander. Com extensa experiência em bancos, Schwartsman passou também pelo Santander, pela BBA Corretora, pela Indosuez WI Carr Securities e pelo Banco ABN Amro Real. Da mesma forma, Zeina Latif foi economista-chefe do ING Bank, do Banco Real, do HSBC e do banco Bilbao Viscaya, assim como trabalhou no Royal Bank of Scotland. Marcos Lisboa foi diretor-executivo e vice-presidente do Itaú Unibanco. Monica de Bolle trabalhou no Banco BBM e foi economista do Fundo Monetário Internacional (FMI).

$\mathrm{Da}$ mesma forma, alguns desses colunistas integraram as equipes formuladoras dos programas de governo de candidatos à presidência do Brasil. José Roberto Mendonça de Barros participou, em 2018, da equipe econômica da campanha de Geraldo Alckmin, candidato pelo Partido da Social Democracia Brasileira (PSDB) (SIMÕES, 2018); Samuel Pessôa contribuiu na formulação da campanha de Aécio Neves (PSDB), em 2014 (ARAÚJO, 2014). Após 28 anos como filiado ao PSDB, Gustavo Franco se transferiu para o Partido Novo (PN) e foi um dos responsáveis pelo plano de governo de João Amoêdo (MARTINS, 2017), em 2018. Claudio Adilson Gonçalez foi o nome escolhido pelo presidente da Câmara, Rodrigo Maia - do Democratas (DEM), partido com o qual Gonçalez mantém relações -, para discutir um possível apoio a Ciro Gomes do Partido Democrático Trabalhista (PDT) (TRUFFI, 2018). O economista afirmou, porém, que as posições eram irreconciliáveis e o partido acabou apoiando a candidatura de Geraldo Alckmin pelo PSDB. Marcos Lisboa não se vinculou a uma campanha específica, mas manteve um diálogo com diferentes candidatos, como Rodrigo Maia (DEM) e Marina Silva da Rede Sustentabilidade (REDE) (VALENTE, 2018), assim como chegou a ser cogitado para o Ministério da Fazenda em um possível governo de Fernando Haddad, candidato pelo Partido dos Trabalhadores (PT) (GASPAR, 2018). Por outro lado, Nelson Barbosa e Laura Carvalho alinharam-se às campanhas dos candidatos mais à esquerda do espectro político - Fernando Haddad, do PT (MARTINS, 2017) e Guilherme Boulos, do Partido Socialismo e Liberdade (PSOL) (DCM, 2018), respectivamente.

Essas trajetórias, aqui apresentadas de forma sintética, ilustram o movimento de portas giratórias entre instituições de ensino, mídia, bancos e cargos de importância política. Se os diplomas de prestígio possibilitaram a essas figuras a ocupação de postos decisivos no campo econômico e político, as experiências profissionais alcançadas nesses postos os tornam atrativos para instituições, especialmente, privadas de graduação e pós-graduação em economia. Mas, além disso, os currículos e as trajetórias assim construídos os permitem também o acúmulo de capital para a atuação 
como consultores em agências próprias ou não. Quase todos são sócios, diretores, presidentes ou economistas-chefes de agências de consultoria, cujo foco de atuação é a orientação de processos decisivos - seja de grandes empresas, políticos, instituições midiáticas ou até mesmo de ensino. Apenas no caso de Laura Carvalho, Nelson Barbosa e Marcos Lisboa não foram encontrados dados sobre vinculação com alguma empresa de consultoria.

Assim, entre veículos de comunicação, cargos políticos e econômicos, instituições de ensino e pesquisa, esses colunistas vão construindo um circuito de troca de ideias e propostas, uma rede de contatos e influências bem como relações de hierarquia, concorrência e cooperação. Nesse sentido, os jornais em que escrevem se configuram, em alguma medida, como vitrines e propagadores de pensamentos econômicos e visões de mundo formuladas em instituições que têm, para além de seus objetivos mais óbvios - ou seja, ensino, pesquisa, execução de políticas públicas, gestão financeira, produção de informação etc. -, o papel de promover a sociabilidade entre os detentores do saber e do pensamento econômico e, consequentemente, uma determinada hegemonia desse pensamento.

\section{O pensamento dominante pró-reformas}

Antes de passarmos à apresentação das tomadas de posição dos economistascolunistas é importante mostrarmos como procedemos à análise. Primeiramente, buscamos em suas colunas, publicadas nos sites dos jornais em que escrevem, todos os textos disponíveis sobre a PEC 241 e as Reformas Trabalhista e da Previdência e selecionamos especialmente os artigos que traziam nos títulos e subtítulos a informação de que tratavam desses temas. Fizemos a leitura das colunas, atentandonos para os argumentos utilizados pelos economistas para defender ou refutar a necessidade de reformas, observando também as comparações, exemplos e estratégias de que lançam mão para dar força às suas opiniões, além de traçarmos as diferenças entre pontos de vista de experts com posições semelhantes.

Com o material coletado, elaboramos um banco de dados a fim de visualizar as informações e examiná-las comparativamente, uma vez que trabalhamos com cem textos, pertencentes aos seguintes nomes: Claudio Adilson Gonçalez (2), Nelson Barbosa (2), José Roberto Mendonça de Barros (4), Gustavo Franco (4), Marcos Lisboa (5), Zeina Latif (6), Affonso Celso Pastore (7), Delfim Netto (11), Laura Carvalho (13), Samuel Pessôa (14), Alexandre Schwartsman (16) e Monica de Bolle (16). 
A partir do estudo do banco de dados, verificamos a existência de dois principais grupos: o dos economistas que celebraram, durante o governo de Michel Temer $^{25}$, as iniciativas que visavam à promoção de reformas - mais numeroso e denominado por nós como pró-reformas; e o grupo dos economistas que apontavam a importância de serem feitos ajustes necessários, que deveriam visar, sobretudo, à arrecadação. Passemos à análise do primeiro grupo.

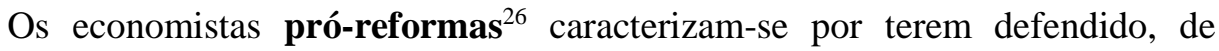
forma geral, medidas de salvação das contas públicas cujo objetivo era a redução dos gastos do governo federal em um momento considerado de crise econômica: "As contas públicas do governo federal são insustentáveis", declarou Lisboa em coluna do dia 17 de dezembro de 2017 (LISBOA, 2017b). Na mesma direção, Pessôa, em coluna do dia 15 de julho de 2018, afirmou a necessidade de criar impostos ou aprovar reformas que reduzissem o gasto, sob pena de retornarmos "aos anos 1980 de triste memória" (PESSÔA, 2018).

Seguindo o argumento desses economistas, caso não fossem levadas a cabo as reformas, os serviços básicos para a população - segurança, saúde, educação e ciência etc. - ficariam comprometidos. Para honrar os compromissos de gastos fixados na Constituição, o governo, segundo Schwartsman (2017b), elevaria o risco fiscal, o que acarretaria o aumento da inflação e da taxa de juros: "A consequência é óbvia: sem reformas, o risco de o desequilíbrio fiscal ter que ser 'resolvido' pela inflação aumenta, levando à piora das expectativas e à elevação da inflação, limitando, assim, a queda da taxa de juros". Monica de Bolle (2018) argumentou na mesma direção: “com as contas públicas destrambelhadas e sem reforma da Previdência, em algum momento a inflação haverá de subir, a turbulência deve voltar, os juros sairão de seu patamar historicamente baixo, e a recuperação esmorecerá". A deterioração das contas públicas e do ambiente econômico em geral poderia, assim, comprometer a solvência do Estado: "Com relação à área fiscal, continua sendo verdadeiro que sem a reforma da Previdência e algum controle sobre a folha salarial das corporações será impossível consolidar a trajetória da dívida pública" (BARROS, 2017);

Nesse sentido, eles celebraram, em suas colunas, a aprovação da PEC 241, em dezembro de 2016: "O governo teve a coragem de atacar a fonte mais importante do

\footnotetext{
${ }^{25}$ Os artigos que tratam das reformas foram publicados no período que vai do final do governo de Dilma Rousseff (2016) até o momento em que realizamos a coleta dos textos, que coincide com o término do período em que Michel Temer ficou na presidência (2017).

26 Da Folha: Samuel Pessôa, Alexandre Schwartsman, Delfim Netto e Marcos Lisboa. Do Estadão: Zeina Latif, Gustavo Franco, Monica de Bolle, Affonso Celso Pastore, Claudio Adilson Gonçalez e José Roberto Mendonça de Barros. Do Globo: Gustavo Franco.
} 
desequilíbrio - o crescimento dos gastos - propondo uma solução eficaz, e não apenas em paliativo, e nossa obrigação é apoiar a decisão" (PASTORE, 2016). Ainda assim, reiteraram também a importância das Reformas Trabalhista (que foi aprovada em julho de 2017) e da Previdência, como verificado no excerto da coluna de 21 de setembro de 2016 de Delfim Netto: "Uma vez aprovado o controle geral de gastos, será preciso enfrentar o problema da Previdência apresentando um programa republicano que, no longo prazo, submeta todos os brasileiros ao mesmo regime".

Gustavo Franco (2017c) seguiu a mesma linha: "Cálculos conservadores indicam que, na ausência da reforma da Previdência, o teto constitucional para o crescimento das despesas do governo tornar-se-á letra morta em pouco tempo".

A promoção das reformas visaria, ainda, para os economistas, a retomada do crescimento econômico, afetado pela crise: "Sem reformas, o retorno ao crescimento fica cada vez mais distante" (SCHWATSMAN, 2017a); "A moral da história é que as reformas macroeconômicas, começando pela da Previdência, são fundamentais para o crescimento, gerando um ambiente de estabilidade e de baixos riscos" (PASTORE, 2017); “O ajuste das finanças públicas é cada vez mais indispensável, e a consolidação da retomada do crescimento depende integralmente disso" (BARROS, 2018a).

No contexto de aprovação da PEC 241, que congela os gastos públicos por até vinte anos (podendo ser revisada depois de dez anos), com cifras corrigidas pela inflação do ano anterior, a Previdência impôs-se como prioridade na agenda de reformas: "Reformar a Previdência não é uma necessidade apenas do ponto de vista do ajuste fiscal. O que está em jogo é a própria sobrevivência do sistema, como já é realidade em alguns estados e municípios que não conseguem mais honrar seus compromissos" (GONÇALEZ, 2018); "Os impactos da previdência na economia são significativos e abrangentes. Talvez seja a política pública que mais impacte a vida das pessoas e a dinâmica da economia. E talvez seja a principal prioridade na agenda de reformas estruturais" (LATIF, 2016). Ainda, de acordo com Monica de Bolle (2016):

Estudo recente do FMI mostra que, sem as reformas, o peso da Previdência sobre o PIB subiria de $10 \%$ para pouco menos de $20 \%$ nos próximos 20 anos - ou seja, a Previdência sugaria praticamente todos os recursos do governo, restando quase nada para o investimento público, os programas sociais, a saúde, a educação, e por aí vai.(BOLLE, 2016).

A reforma das aposentadorias é considerada importante pelos economistas devido ao aumento da expectativa de vida no país. De acordo com eles, o sistema atual 
encontra-se em perigo devido às mudanças demográficas: "É um sistema, digamos assim, 'da mão para a boca', ou mais precisamente de uma mão (jovem) para outra boca (inativa), e que pode ficar seriamente desequilibrado com as mudanças demográficas" (FRANCO, 2018); "O Brasil está muito atrasado na Reforma da Previdência. Muitos países já a fizeram nos últimos 30 anos, para fazer frente ao envelhecimento da população" (LATIF, 2017c). Comparações com outros países servem para dar corpo ao argumento dos experts: "Somos um país jovem e desigual que gasta com previdência $13 \%$ do PIB, mais do que o Japão, que tem três vezes mais idosos" (LISBOA, 2017b).

É importante assinalar que os economistas colunistas apresentam posições diferentes quanto às regras das reformas que deveriam ser aprovadas pelo governo. Em seus artigos, comentam favoravelmente ou criticamente as revisões realizadas quando em tramitação no governo e nas casas legislativas. Contudo, de forma geral, são defensores de uma versão mais radical, que promova maiores transformações nas leis existentes. Um exemplo dessa radicalidade é a defesa, por Zeina Latif, de que a idade de aposentadoria de homens e mulheres seja igualada: "Igualar a idade de aposentadoria de homens e mulheres é importante iniciativa, em função da maior expectativa de vida das mulheres (em 2013, a sobrevida das mulheres com 65 anos era de 20 anos, contra 16 dos homens)" (LATIF, 2017a). Além disso, é possível citar a queixa de Monica de Bolle (2017b) a respeito da reforma Trabalhista que era discutida pelo governo: "A modernização das leis trabalhistas choca-se com os mais diversos e esperados obstáculos, forçando o débil governo de Michel Temer a fazer concessões que transformarão tal reforma em quase nada, esgarçando mais cordas fundamentais da pinguela".

Para alguns economistas, as reformas Trabalhista e da Previdência encontravam resistências à sua aprovação devido ao medo de alguns grupos sociais funcionários públicos que recebem altos salários e sindicatos, principalmente perderem seus privilégios. Como apontou Marcos Lisboa (2017b): "afinal, quais são as resistências à reforma da Previdência? Certamente, perde a elite mais bem remunerada dos servidores públicos com a redução de privilégios concedidos a grupos que estão entre os $5 \%$ ou mesmo entre o $1 \%$ mais rico da população". Sua argumentação, nos artigos, vai no sentido de demonstrar que com a reforma da Previdência os mais prejudicados seriam os mais ricos, o que é contradito por Laura Carvalho, por exemplo. Em coluna do dia 14 de janeiro de 2016, Zeina Latif escreve, também, que:

Há avanços na remoção de distorções distributivas, pela 
eliminação de aposentadorias precoces e de acúmulo de benefícios e redução de regimes especiais, que beneficiam os mais ricos. Os mais pobres serão preservados, pois continuarão recebendo o mínimo e se aposentando por idade (35\% dos beneficiários). (LATIF, 2016).

Lisboa e Latif (2013), que produziram um working paper a respeito da democracia de meia entrada brasileira, na qual alguns grupos privilegiados se beneficiam de um mecanismo de transferência de renda do Estado (o que chamam de meias-entradas), advogam em favor de uma agenda republicana, promotora de uma pretensa igualdade, resultante das reformas que devem ser promovidas no Brasil: "É necessário eliminar distorções distributivas nas regras atuais. A previdência dá tratamento especial para grupos que deveriam ter tratamento igual” (LATIF, 2017a).

Em coluna sobre as reformas, Gustavo Franco (2017a) concordou com Marcos Lisboa, repudiando o tratamento desigual entre as pessoas: "O seletivismo é um demônio mais discreto e insinuante. Aparece, às vezes, pelo nome de "síndrome de meia entrada", mas, a bem da verdade, está em toda parte (...). O demônio do seletivismo tem horror à impessoalidade própria dos mercados e à meritocracia."

Outros economistas, comentando a reforma Trabalhista (aprovada em 26 de abril de 2017), seguem o mesmo argumento das meias-entradas, apresentando os sindicatos, por exemplo, como privilegiados (por cobrarem o imposto sindical): "Finalmente, a decisão termina com uma excrescência [o imposto] que transformou a maioria dos sindicatos em negócios e que desobrigava, na prática, a realizar maiores prestações de serviços e de contas para os trabalhadores das categorias" (BARROS, 2018b). Segundo Gustavo Franco (2017b): "Entre outros progressos, resta mencionar o fim do imposto sindical, essa abominação cuja durabilidade não se consegue explicar. (...) A imensa maioria dessas entidades só existe para captar esse recurso. Nenhuma boquinha terminou no Brasil sem certa dose de esperneio e gás lacrimogênio."

Mesmo que em seus textos elabore posicionamentos e justificações um pouco diversas dos demais economistas, Delfim Netto celebrou, também, a aprovação da Reforma Trabalhista, uma vez que ela acabou com o privilégio dos sindicatos: "Setenta anos de CLT deram nisso: 17 mil sindicatos gozando do monopólio geográfico e da segurança financeira, tão acomodados e seguros que podem até servir ao 'capital' contra os interesses dos seus associados, como se provou na Operação Lava Jato" (NETTO, 2017).

Para os experts, a aprovação da Reforma Trabalhista significa o desmonte da 
rigidez da Consolidação das Leis do Trabalho (CLT). Com a flexibilização das leis, há abertura para celebração de acordos entre capital e trabalho, supostamente elevando a empregabilidade e possibilitando o crescimento econômico. A modernização da legislação geraria uma maior produtividade do trabalho, o que redundaria, da mesma forma, em desenvolvimento econômico.

Mais uma vez, apesar da particularidade de seus argumentos, Delfim Netto concordou com os demais economistas:

A nova lei não é uma panaceia que vai aumentar o emprego imediatamente, mas certamente permitirá relações mais razoáveis entre o "capital" e o "trabalho". Tal cooperação tem soma positiva, o que aumentará a produtividade do trabalho (a definição de crescimento econômico) e gerará uma distribuição mais equânime do produzido. (NETTO, 2017).

É interessante notar que na raiz do argumento dos economistas pró-reforma está a concepção do trabalhador como um sujeito racional, que pode agir no mercado visando o bem próprio. A flexibilização da CLT, dessa forma, não favoreceria só empregador, mas também o empregado, visto que ele poderia negociar situações mais vantajosas para si:

Na verdade, há um substrato profundamente autoritário na ideia de que os direitos dos trabalhadores, em muitos casos, não estão "disponíveis". Isso quer dizer que você não é livre para abrir mão de seu direito porque você é considerado hipossuficiente, isto é, um incapaz diante da lei, e daí se justifica a necessidade de inflar indevidamente o papel do Estado. Para reduzir essa distorção, é muito importante o dispositivo que estabelece, para muitos temas do contrato de trabalho, o primado do pactuado sobre a lei. (FRANCO, 2017b).

Ainda no tocante à Reforma Trabalhista, essa atenderia, segundo os experts, às mudanças que têm acontecido no mundo do trabalho devido à introdução da tecnologia da informação e da intensificação da globalização. Ademais, conforme indicam, cada vez mais, novos tipos de trabalho não precisam ser realizados em um lugar específico, confinados na fábrica ou no escritório - tal flexibilidade é tratada, por exemplo, por Monica de Bolle em coluna do dia 29 de março de 2017 (BOLLE, $2017^{\mathrm{a}}$ ) e por Delfim Netto no dia 04 de outubro de 2017.

Cabe apontar que os experts rebatem, em suas colunas, críticas feitas às 
reformas, as quais são respondidas, por exemplo, remetendo o crítico à condição de privilegiado ou de defensor de privilégios:

Os argumentos tortuosos de que não há um problema na Previdência foram desmoralizados pelos fatos. A maior transparência dos benefícios dos servidores públicos revelou que muitos recebem mensalmente mais de $\mathrm{R} \$ 30$ mil e estão no grupo dos $1 \%$ mais ricos em um país com renda média mensal abaixo de R\$ 3.000. Curiosamente, são defendidos por vários que se definem como de esquerda. (LISBOA, 2018).

Quando a crítica é endereçada ao argumento de outro colunista, colega de jornal, geralmente do outro grupo (dos que não são pró-reformas), seguem-se, nas colunas, debates, baseados, na maioria das vezes, em provas pretensamente fornecidas por dados numéricos. A título de exemplo, citamos uma das respostas de Samuel Pessôa em debate com Laura Carvalho a respeito da reforma da Previdência:

Laura Carvalho e eu temos debatido diversos aspectos da reforma da Previdência. Em sua resposta na quinta-feira (23), ocorreram três avanços. A fila andou. (...) Penso que a discordância que há entre mim e Laura é que eu vejo ligação entre crescimento permanente do gasto primário do Estado acima do crescimento do PIB - tem sido assim nos últimos 25 anos - e baixa poupança, taxa de juros reais elevadas, pressão inflacionária constante e baixo crescimento. Enquanto Laura não enxerga essa ligação. Laura é mais feliz do que eu. (PESSÔA, 2017b).

E a resposta de Alexandre Schwartsman a Nelson Barbosa:

Já o funeral é o da lógica. Em coluna publicada na sexta-feira (21), Nelson Barbosa aponta Portugal como um país que fez o ajuste fiscal sem "austericídio", presumivelmente em oposição ao que se tenta fazer no Brasil. Como de hábito, faltou a Barbosa olhar os números: entre 2010 e 2016 o déficit público em Portugal caiu de $11,2 \%$ do PIB para 2,0\% do PIB, com corte de despesas no período pouco inferior a $7 \%$ do PIB. No Brasil, em contraste, propõe-se uma redução de 2,0-3,0\% do PIB do déficit primário no mesmo horizonte, mas aqui, por alguma razão, esse ajuste muito mais gradual é considerado "austericídio". (SCHWARTSMAN, 2017b). 
O pensamento dominado dos "ajustes necessários": o foco deve estar na arrecadação

De todos os economistas pesquisados, somente Laura Carvalho e Nelson Barbosa contrapõem-se ao pensamento econômico pró-reformas - é interessante notar que os dois realizaram suas pesquisas de doutorado na New School for Social Research e se alinharam às campanhas identificadas mais à esquerda do espectro político em 2018. Além disso, ambos escrevem para a Folha de S.Paulo.

Nelson Barbosa, no início de 2016, foi Ministro da Fazenda de Dilma Rousseff. Quando estava no cargo, defendia a necessidade de realização de reformas, que, segundo ele, foram incorporadas pelo governo de Temer, mas com foco menor na arrecadação (BARBOSA, 2017b). Laura Carvalho, embora, em sua coluna, dê ênfase aos problemas das propostas colocadas em tramitação nas casas legislativas, concorda com Barbosa, sobre o fato de que os ajustes devem ser feitos para aumentar a receita do Estado: "Além de não levar em conta nossas desigualdades profundas, a reforma de Temer concentra todas as mudanças no lado das despesas, sem nenhuma preocupação com a base de arrecadação do sistema" (CARVALHO, 2017a).

À semelhança dos experts pró-reformas, Barbosa (2017b) justifica a necessidade da reestruturação da Previdência com base nas mudanças demográficas que estão ocorrendo no país - queda da taxa de natalidade e aumento da expectativa de vida. Apesar de concordar, tal qual os reformistas, que há injustiça distributiva no sistema previdenciário, "que faz com que servidores públicos se aposentem em condições muito mais favoráveis do que trabalhadores do setor privado" (BARBOSA, 2017b), o ex-ministro parece não ser adepto da teoria da meia-entrada. Sua argumentação pró-reformas, mas divergente do pensamento econômico dominante, fica expressa no excerto a seguir:

Há várias formas de reformar as aposentadorias, como indica nossa história recente. Por exemplo, depois de perder a votação da idade mínima por um voto, FHC criou o fator previdenciário, o que aumentou o déficit do INSS no curto prazo e não resolveu o problema de longo prazo (mas não conte isso a tucanos). Os governos que mais reformaram a Previdência de modo permanente foram do PT (mas não conte isso a petistas). Lula iniciou seu governo com uma reforma sobre os servidores civis - fixando idade mínima e criando contribuição de inativos - que, apesar de 
não resolver todo o problema, estabilizou o gasto federal com esses benefícios em proporção do PIB. Dilma também adotou medidas estruturais, como a criação do fundo de pensão para novos servidores civis, em 2012, e a mudança nas regras de concessão de novas pensões por mortes e auxílio-doença pagos pelo INSS, em 2015. Mesmo com os avanços dos últimos anos, todos eles nos governos do PT, ainda é preciso fazer mais na Previdência. (BARBOSA, 2017b).

É como se o economista, com o seu saber, conseguisse enxergar que a Reforma da Previdência está acima das questões partidárias, mas sempre salientando que foi o governo do PT o mais aberto e o promotor principal das reformas necessárias.

Quando escreve sobre a Reforma Trabalhista, Barbosa justifica sua importância indicando o quanto a modernização da CLT é central para aumentar a produtividade do trabalho e promover um melhor funcionamento da economia - tal como os economistas pró-reforma. Recorrendo a exemplos de outros países, assinala, da mesma maneira, que eles realizaram reestruturações tendo em vista as mudanças no mundo do trabalho decorrentes das transformações tecnológicas e da globalização (BARBOSA, 2017a). No entanto, ressalva: lá as reformas também garantiram maior segurança ao trabalhador (seguro-desemprego, alto grau de sindicalização etc.).

$\mathrm{O}$ economista é crítico à Reforma Trabalhista aprovada pelo governo Temer, já que "ela diminui demasiadamente o poder de barganha dos trabalhadores" (BARBOSA, 2017a). Barbosa argumenta, contrariamente aos economistas próreformas, que "flexibilizar leis trabalhistas em momento de lento crescimento tende a aumentar, ao invés de diminuir, a taxa de desemprego no curto prazo" (BARBOSA, 2017a). Ademais, ele defende que não deve ser tirado o poder dos sindicatos com a reforma, pelo contrário: "E deve-se incluir, também, uma cláusula que exija um nível de sindicalização para que o negociado prevaleça sobre o legislado" (BARBOSA, 2017a). Por isso, segundo o expert, o texto que foi aprovado é o de "uma reforma capenga, que propositalmente esqueceu de dar segurança aos trabalhadores" (BARBOSA, 2017a).

Também no artigo sobre as mudanças na legislação trabalhista, a estrutura de sua argumentação segue no caminho de demonstrar que os governos petistas foram bem mais abertos à realização dos ajustes necessários:

No Brasil, a Reforma Trabalhista está em discussão há muito tempo. Por exemplo, o governo Lula criou o Fórum Nacional do 
Trabalho, que apresentou uma proposta de emenda constitucional para a Reforma Trabalhista. A iniciativa não prosperou. Durante o governo Dilma, houve uma proposta mais focalizada de criação do Acordo Coletivo Especial, para promover o negociado sobre o legislado, via projeto de lei, sem sucesso. Apesar do bom desempenho do mercado de trabalho até 2014, essas duas iniciativas de reforma não prosperaram por resistências dentro do próprio movimento trabalhista. Agora temos as consequências. Quando a esquerda não faz a reforma necessária no tempo correto, ela acontece além do necessário no momento errado. (BARBOSA, 2017a).

Laura Carvalho, como já foi dito, coloca-se contra as reformas propostas - e aprovadas - nos últimos anos. Sua argumentação vai no sentido de demonstrar que elas podem agravar alguns dos problemas que dizem resolver: a desigualdade social e o desemprego. Segundo a economista, por exemplo,

(...) ajustes no sistema previdenciário serão sempre necessários para adaptar-se às mudanças demográficas de cada país. A pergunta crucial - e que, finalmente, vem ganhando algum espaço no debate brasileiro sobre a reforma da Previdência é se as mudanças propostas pelo governo contribuirão para a ampliação das desigualdades ou, ao contrário, reduzirão sobretudo os privilégios. (CARVALHO, 2017b).

Em artigo anterior ela defendera o argumento de que a reforma da Previdência contribuiria para aumentar a desigualdade, sendo os pobres os mais prejudicados:

Segundo estudo de 2015 do Ministério do Trabalho e da Previdência Social, os benefícios sozinhos são responsáveis por reduzir o percentual de pobres no Brasil de $37,8 \%$ para $24,2 \%$. Defender que a diminuição drástica na cobertura e no valor das aposentadorias não ampliará nossas desigualdades é passar longe da realidade das famílias brasileiras (...). Quanto aos efeitos da reforma proposta, seu impacto é mesmo maior sobre quem começou a trabalhar mais cedo e nas piores condições. (CARVALHO, 2017a).

Quando comenta a PEC 241, a economista também sinaliza os efeitos de desigualdade que ela acarreta - dessa vez entre os setores que disputam fatias do 
orçamento público - em claro diálogo com Delfim Netto:

Mesmo diante de todas as evidências de que a PEC/95 levará a uma paralisação da máquina pública após alguns anos, sua adoção continua a ser defendida como um artifício para a aprovação da reforma previdenciária e de outras medidas impopulares, pois tornariam mais transparente o conflito distributivo sobre os itens do Orçamento público. Nessa hipótese, os diferentes setores da sociedade que disputam as fatias do Orçamento público seriam levados pela escassez a fazer a divisão mais justa possível do bolo. Em tese, os representantes das áreas prioritárias para a sociedade, ao se deparar com cortes cada vez maiores no seu Orçamento, passariam a defender que se tirasse dinheiro dos mais privilegiados. Até parece. Como a regra vai se tornando mais rígida ao longo do tempo, o procedimento equivale a trancar em uma sala os representantes de cada uma das áreas para onde se destinam recursos federais para brigar por um bolo que vai diminuindo cada vez mais de tamanho. O problema é que em jogos desse tipo já sabemos de antemão quem sairá vencedor: o mais forte. (CARVALHO, 2018b).

Carvalho opõe-se, dessa maneira, ao grupo pró-reformas. Igualmente, sua opinião vai de encontro à premissa básica daqueles que defendem a Reforma Trabalhista, qual seja, a de que a flexibilização da CLT fomentaria a formalização, a produtividade do trabalho o que, consequentemente, levaria ao crescimento econômico, conforme pode ser verificado em coluna do dia 02 de agosto de 2018 (CARVALHO, 2018a). A professora da USP contesta, inclusive, a tese de que a Reforma Trabalhista, nos moldes em que foi aprovada, permite ao país melhor enfrentar os desafios impostos ao mundo do trabalho no século XXI:

Construir uma agenda para a modernidade não significa, portanto, confundir trabalhadores autônomos em clara situação de dependência econômica com os empreendedores altamente qualificados da era da internet e do "home office", que também proliferam em todo o mundo (...). Na reforma trabalhista, aprovada na Câmara nesta quarta (26), por sua vez, além da falta de debate com a sociedade, não há modernidade alguma. Afinal, não há nada de mais arcaico do que aumentar ainda mais o poder dos que já o têm de sobra (CARVALHO, 2017c). 
No mesmo artigo, Carvalho (2017c) reforça que "a desregulamentação do mercado de trabalho não eleva, ou até mesmo prejudica, o nível de emprego", mais uma vez em franca oposição aos economistas pró-reformas.

\section{O vai e vem entre posições e tomadas de posição - o jornalismo especializado e a doxa liberal}

Os economistas-colunistas que constituíram o objeto desta análise circulam em espaços importantes de definição de agendas políticas para o país - cargos em ministérios e secretarias, participação nos bastidores, como elaboradores de programas econômicos de candidatos à Presidência, etc. -, em agências financeiras que cuidam do dinheiro do empresariado brasileiro, e em instituições importantes de elaboração e difusão do pensamento - universidades e grandes jornais do país. Tendo acesso a vários espaços da cadeia de produção e difusão de ideias, conseguem impor o seu quase monopólio sobre aqueles que consomem seus produtos - principalmente, o grupo específico de agentes econômicos e políticos para o qual trabalham nas assessorias e que, possivelmente, constitui também seu principal público leitor nas colunas.

O pensamento econômico - por ter como produtores e difusores agentes que transitam entre universos tão variados, tendo as credenciais para ocupar posições dominantes nesses espaços, e também por ser expresso em uma linguagem cifrada, com base em dados trabalhados econometricamente - ganha poder simbólico na busca pela forma verdadeira de explicação do mundo social. Os economistas, nesse sentido, são verdadeiros sacerdotes ${ }^{27}$, que anunciam com base em previsões que não podem ser comprovadas por um não iniciado - e, em muitos casos, nem por outros iniciados, que ocupam hierarquias ou posições diferentes no espaço da economia -, os humores do mercado. Suas falas (suas escritas) têm um forte poder performativo (BOURDIEU; DELSAUT, 2001), já que eles mesmos ou pessoas próximas, baseados em seus prognósticos, podem tornar real o que anunciam.

Tendo isso em vista, cumpre interpretar o que significa, para os jornais, ter como colunistas tais figuras. Nesse sentido, há algumas diferenças que podem ser traçadas brevemente em relação aos jornalistas que ocupam o mesmo lugar. Em

${ }^{27}$ Para uma abordagem acerca da utilidade da sociologia da religião na compreensão de processos simbólicos, ver: BOURDIEU (2015). Embora trate do campo religioso, o texto é ilustrativo dos processos de monopolização dos bens de salvação presentes também em outros campos, como o econômico. 
entrevista publicada no livro Eles mudaram a imprensa - depoimentos ao CPDOC, o jornalista Augusto Nunes fala sobre a importância da grife $^{28}$ nos jornais, ou seja, da assinatura de conteúdo por parte de algum jornalista prestigiado na busca por leitores:

Para diferenciar o jornal dos outros veículos, para que ele tenha o seu espaço num mercado em que estão o rádio, a revista e a televisão, você tem de usar griffes. E a griffe estará associada a fórmulas imortais, como entrevistas e perfis. (...) Mas uma griffe fará as perguntas certas, escreverá um belo perfil, e o leitor vai ler com atenção (ABREU et al., 2003, p.324).

Assim, os colunistas-jornalistas, em geral, carregam uma espécie de grife, que os autorizam a assinar seus textos e, mais do que isso, a publicar interpretações e opiniões sobre os fatos, ocupando, portanto, posições de prestígio dentro do jornalismo. Tal grife é construída, sobretudo, pela trajetória profissional (BERGAMO, 2011), constituída pelas reportagens realizadas, pelas fontes cultivadas, pelos fatos históricos testemunhados - ou seja, pelas experiências tidas como singulares, dissimulando os aspectos socialmente compartilhados por esses agentes. No caso dos colunistas-economistas, a legitimidade parece ser construída sobretudo pelo pertencimento a uma classe de profissionais - ou mais do que isso, à elite dessa classe -, que compartilha formações acadêmicas, ocupações de cargos políticos e no setor privado, assim como visões de mundo - ainda que, quanto mais consagrados enquanto colunistas e maior a hierarquia que ocupam dentro dessa elite profissional, mais os aspectos singulares das trajetórias desses agentes sejam reforçados.

A diferença entre como se dá a utilização da grife pelos colunistas-jornalistas e pelos colunistas-economistas deve-se à posição ocupada por eles no mundo jornalístico. Enquanto para os primeiros a posse da grife atesta um tipo de excelência, é o grau máximo alcançado por um jornalista bem-sucedido, marca de uma trajetória ímpar, para os experts escrever para um grande jornal nada mais é do que uma dentre as funções que ocupa. É possível conjecturar que, quanto mais o economista é famoso, isto é, participa da vida pública, está sempre circulando em diferentes mídias, mais sua presença é requisitada pelos jornais. Desse modo, quanto mais próximo do campo jornalístico - em outras palavras, quanto mais depende da presença na imprensa para

\footnotetext{
28 O termo utilizado pelos jornalistas guarda proximidades com aquele sociologicamente construído por Bourdieu e Delsaut (2001, p.38), sem porém o seu conteúdo desvelador, já que a análise sociológica não restaura "a fé no poder carismático do criador", mas insere a criação dessa grife na estrutura do campo a que se refere.
} 
ter legitimidade e para garantir sua posição na hierarquia da elite profissional - mais o seu tipo de grife se aproximará da jornalística, individual, tornando-se mais independente da validação pelo pertencimento a um grupo de pares.

Em ambos os casos, "a imposição da 'grife' consuma - embora por vias radicalmente opostas -, os fins que persegue a publicidade" (BOURDIEU, DELSAUT, 2001, p.41). Nesse sentido, o capital simbólico, construído a partir dos nomes que fornecem sua grife ao jornal, pode se converter em capital econômico, na atração de anunciantes, investidores e leitores. Os economistas podem, ainda, atuar, enquanto experts - detentores de um conhecimento técnico específico -, na ratificação de determinadas posições interessadas dos veículos em que trabalham, estando em consonância em termos de visão de mundo com essas empresas.

Portanto, a contratação de colunistas-economistas de cepa liberal indica o compartilhamento de um pensamento econômico dominante não apenas entre uma elite do mundo econômico e uma elite do jornalismo de economia (PEDROSO; UNDURRAGA, 2016), mas também entre esses agentes e os valores organizacionais dos jornais para os quais trabalham. Negando o conteúdo político de suas teses, consideradas como frutos de evidências empíricas (fundadas sobretudo em princípios matemáticos), os jornais e seus colunistas ensaiam uma despolitização, conforme Duval (2004) também verificou na imprensa econômica francesa.

Ainda assim, o que se observa é que esse pensamento tem também um conteúdo partidário. Conforme visto na parte dedicada à morfologia social dos economistas-colunistas, os defensores de um pensamento pró-reformas tendem a se ligar a candidatos situados mais à direita do espectro político (embora nem todos se considerem de direita e alguns tenham até mesmo expresso, na eleição de 2018, apoio a candidatos mais ao centro ou centro-esquerda - como Monica de Bolle em relação a Ciro Gomes - ou dialogado com candidatos de centro-esquerda ou esquerda - como Marcos Lisboa com Fernando Haddad), enquanto os economistas divergentes - Laura Carvalho e Nelson Barbosa - têm ligações evidentemente mais próximas com partidos situados mais à esquerda. $\mathrm{O}$ fato de que a grande maioria dos economistas que têm colunas nos jornais seja pró-reformas ilustra a afirmação de que a imprensa, na prática, toma partido, contrariando, por exemplo, a ideia de isenção, apartidarismo e pluralismo, pregada por alguns veículos. 


\title{
The COLUMNIST-ECONOMISTS IN THE DEBATE OF THE REFORMS IN BRAZIL
}

\begin{abstract}
This paper analyzed the dynamics established between the positions of the columnist-economists in the field of power and their position-takings about the PEC 241 and the reforms of Social Security and Labor. The research object was the economists that are also columnists of the main general-interest newspapers of the country - Folha de S.Paulo, O Estado de S. Paulo and O Globo. Outlining their positions in relation to the economic and political powers as well as to the academic field and the media, and analyzing their discourses about the reforms, it was possible to understand the symbolic exchanges that these agents establish among themselves as well as with the newspapers in which they write. We also underline the importance of these agents for the ratification and reiteration of certain projects for the country, as diffusers of a doxa constructed in places where agents from different social fields establish exchanges.
\end{abstract}

KEYWORDS: Economists. Journalism. Field of Power. Reforms.

\section{LOS ECONOMISTAS COLUMNISTAS EN EL DEBATE DE LAS REFORMAS EN BRASIL}

RESUMEN: Esta investigación analizó la dinámica establecida entre las posiciones de los economistas columnistas en el campo del poder y sus posiciones en el PEC 241 y las reformas de la Seguridad Social y el Trabajo. Con este fin, hemos adoptado como objeto a los economistas columnistas de los principales periódicos generalistas del país: Folha de S.Paulo, O Estado de S. Paulo y O Globo. Esbozando sus posiciones en relación con los poderes económicos y políticos, así como con el campo académico y los medios de comunicación, y analizando sus discursos sobre las reformas, fue posible comprender los intercambios simbólicos que estos agentes establecieron entre ellos, así como con los periódicos en los que escriben. Destacamos también la importancia de estos agentes para la ratificación y reiteración de ciertos proyectos para el país, siendo difusores de una doxa construida en lugares donde agentes de diferentes ámbitos sociales establecen intercambios.

PALABRAS Cla VE: Economistas. Periodismo. Campo de Poder. Reformas. 
Referências

ABREU, A. A. Jornalistas e jornalismo econômico na transição democrática. In: . LATTMAN-WELTMAN, F.; KORNIS, M.A. Mídia e política no Brasil - jornalismo e ficção. Rio de Janeiro: Editora FGV, 2003.

ABREU, A. A; LATTMAN-WELTMAN, F.; ROCHA, D. Eles mudaram a imprensa - depoimentos ao CPDOC. Rio de Janeiro: Editora FGV, 2003.

ABREU, A. A.; ROCHA, D. Elas ocuparam as redações - depoimentos ao CPDOC. Rio de Janeiro: Editora FGV, 2006.

ALMEIDA, A. M. F. O assalto à educação pelos economistas. Tempo Social, Revista de Sociologia da USP, v. 20, n. 1. Disponível em: 〈www.scielo.br > pdf〉. Acessado em 06 nov. 2019.

ARAÚJO, C. Economista da FGV confirma trabalho com Aécio. O Estado de S. Paulo, 02 abr. 2014. Disponível em: <https://politica.estadao.com.br/noticias/geral,economista-da-fgv-confirma-trabalhocom-aecio,1148188>. Acessado em: 08 abr. 2018.

BARBOSA, M. História cultural da imprensa. Rio de Janeiro: Mauad, 2007.

BERGAMO, A. Reportagem, Memória e História no jornalismo brasileiro. Mana, v. 17, n. 2, p.233-269, 2011.

BOURDIEU, P. Homo Academicus. Paris: Éd. de Minuit, 1984.

A Economia das Trocas Simbólicas. São Paulo: Editora Perspectiva, 2015.

BOURDIEU, P.; DELSAUT, Y. O costureiro e sua grife: contribuição para uma teoria da magia. Educação em Revista, Belo Horizonte, n. 34, p. 7-66, dez. 2001.

BROADCAST. Disponível em: <http://broadcast.com.br/>. Acessado em: 08 abr. 2018.

CARLOTTO, M. C. Universitas semper reformanda? A Universidade de São Paulo 
e o discurso da gestão à luz da estrutura social. 2014. 570 f. Tese (Doutorado em Sociologia) - Programa de Pós-Graduação em Sociologia. Faculdade de Filosofia. Letras e Ciências Humanas. Universidade de São Paulo, São Paulo, 2014.

CARTA CAPITAL. A crise política e o desânimo do povo com seus representantes. Carta Capital, 29 set. 2017. Disponível em: $<$ https://www.cartacapital.com.br/politica/a-crise-politica-e-o-desanimo-do-povo-comseus-representantes/>. Acessado em: 08 abr. 2018.

CHIARAMONTE, A. R. Lutas simbólicas e doxa: jornalistas e acadêmicos no caso da 'lista dos improdutivos' da USP. 2015. 214f. Dissertação (Mestrado em Sociologia) - Programa de Pós-graduação em Sociologia, USP, São Paulo, 2015.

DCM. Economista Laura Carvalho entra na campanha de Boulos: vamos entregar um programa de combate às desigualdades. Diário do Centro do Mundo, 30 mar. 2018. Disponível em: <https://www.diariodocentrodomundo.com.br/essencial/economistalaura-carvalho-entra-na-campanha-de-boulos-vamos-entregar-um-programa-decombate-as-desigualdades/>. Acessado em: 08 abr. 2018.

DUVAL, J. Critique de la Raison Journalistique. Paris: Éd. Le Seuil, 2004.

ESTADÃO. AE no mundo das negociações eletrônicas. O Estado de S. Paulo, São Paulo, 01 abr. 2009.

ESTADÃO. 'Estado' lança serviço pioneiro na web. Estadão, 25 fev. 2011. Disponível em: <https://economia.estadao.com.br/noticias/geral,estado-lanca-servicopioneiro-na-web,56764e>. Acessado em: 04 set. 2009.

ESTADÃO. Notícias na mão do investidor. O Estado de S. Paulo, São Paulo, 13 nov. 2006.

ESTADÃO. Clientes aprovam compra da Broadcast pela AE. O Estado de S. Paulo, São Paulo, 14 ago. 1991.

ESTADÃO. Agora é fácil negociar ações e commodities. O Estado de S. Paulo, São Paulo, 01 nov. 1988. 
ESTADÃO. Curso Estado de Jornalismo Econômico. Estadão, 19 fev. 2012. Disponível em: <https://brasil.estadao.com.br/blogs/em-foca/curso-estado-dejornalismo-economico/>. Acessado em: 08 abr. 2018.

FUCS, J. O Brasil além da crise. O Estado de S. Paulo, 17 jun. 2017. Disponível em: $<$ https://economia.estadao.com.br/noticias/geral,o-brasil-alem-dacrise,70001846146>. Acessado em: 08 abr. 2018.

GASPAR, M. Marcos Lisboa: Me comparar a Paulo Guedes é demais. Piauí, 19 set. 2018. Disponível em: <https://piaui.folha.uol.com.br/marcos-lisboa-me-compararpaulo-guedes-e-demais/>. Acessado em: 08 abr. 2018.

G1. Grupo Folha vende participação no 'Valor Econômico' para Grupo Globo. G1, 13 set. 2016. Disponível em: <http://g1.globo.com/economia/midia-emarketing/noticia/2016/09/grupo-folha-vende-participacao-no-valor-economico-paragrupo-globo.html>. Acessado em: 08 abr. 2018.

HERMIDA, X. Brasil, um gigante abatido. El país, 08 abr. 2018. Disponível em: <https://brasil.elpais.com/brasil/2018/04/07/politica/1523127625_584461.html>. Acessado em: 08 abr. 2018.

KLUGER, E. Meritocracia de laços: gênese e reconfigurações do espaço dos economistas no Brasil. 2017. 855 f. Tese (Doutorado em Sociologia) - Faculdade de Filosofia, Letras e Ciências Humanas, Universidade de São Paulo, São Paulo, 2017.

LISBOA, M.; LATIF, Zeina. Democracy and grow in Brazil. Insper working paper, n. 311, 2013. Disponível em: <https://www.insper.edu.br/wpcontent/uploads/2013/07/Democracy and Growth in Brazil.pdf $>$. Acessado em: 30 de out. 2019.

LOUREIRO, M. R. A participação dos economistas no governo. Análise, Porto Alegre, v. 17, n. 2, p. 345-359, jul./dez. 2006.

MARTINS, F. Idealizador do Plano Real vira garoto-propaganda do presidenciável da nova direita. Gazeta do Povo, 24 dez. 2017. Disponível em: <https://www.gazetadopovo.com.br/politica/republica/eleicoes-2018/idealizador-doplano-real-vira-garoto-propaganda-do-presidenciavel-da-nova-direita- 
19e4lqwbbg4t7zkcrm27zzxvb/>. Acessado em: 08 abr. 2018.a

MORAES, V. A elite dos jornalistas brasileiros: estratégias de legitimação e simbolização entre o período ditatorial e os anos pós-redemocratização. 2017. 481 p. Tese (Doutorado em Sociologia Política) - Centro de Filosofia e Ciências Humanas, Universidade Federal de Santa Catarina, Florianópolis, 2017.

PEDROSO, A.; UNDURRAGA, T. Jornalistas da economia e homens das finanças: uma dominação via imperativos profissionais? In: ANPOCS, 40, 2016. Anais eletrônicos... Caxambu: ANPOCS. Disponível em: $<$ http://www.anpocs.com/index.php/papers-40-encontro/mr-7/10001-mr15-jornalistasda-economia-e-homens-das-financas-uma-dominacao-via-imperativos-profissionais1/file>. Acessado em 10 out. 2019.

PULITI, P. A Financeirização do noticiário econômico no Brasil (1989-2002). 2009. 286 p. Tese (Doutorado em Comunicação) - Departamento de Jornalismo e Editoração, Escola de Comunicação e Artes, Universidade de São Paulo, São Paulo, 2009.

RIBEIRO, A.P.G. Jornalismo, literatura e política: a modernização da imprensa carioca nos anos 1950. Estudos Históricos, Rio de Janeiro, n. 31, p. 147-160, 2003.

SIMÕES, E. Alckmin anuncia Bacha, José Roberto e Alexandre Mendonça de Barros para equipe de campanha. $O$ Globo, [2018?]. Disponível em: <https://oglobo.globo.com/economia/alckmin-anuncia-bacha-jose-roberto-alexandremendonca-de-barros-para-equipe-de-campanha-22690773>. Acessado em: 08 abr. 2018 .

THE NEW SCHOOL FOR SOCIAL RESEARCH. Disponível em: <https://www.newschool.edu/nssr/economics/>. Acessado em: 08 abr. 2018

TREVIZAN, K. Brasil enfrenta pior crise já registrada poucos anos após um boom econômico. G1, 07 mar. 2017. Disponível em: <https://g1.globo.com/economia/noticia/brasil-enfrenta-pior-crise-ja-registradapoucos-anos-apos-um-boom-economico.ghtml>. Acessado em: 08 abr. 2018.

TRUFFI, R. Economista ligado ao DEM rejeita ideias de Ciro em reunião com 
assessor. O Estado de S. Paulo, 18 jul. 2018. Disponível em: $<$ https://politica.estadao.com.br/noticias/geral,economista-ligado-ao-dem-rejeitaideias-de-ciro-em-reuniao-com-assessor,70002406784>. Acessado em: 08 abr. 2018.

UNDURRAGA, T. Making News, Making the Economy: Technological changes and Financial Pressures in Brazil. Cultural Sociology, 22 fev. 2016. Disponível em: <https://journals.sagepub.com/doi/full/10.1177/1749975516631586>. Acessado em: 20 out. 2019.

VALENTE, G. Quem são os conselheiros econômicos dos pré-candidatos à Presidência? Época, fev. 2018. Disponível em: $<$ https://epoca.globo.com/economia/noticia/2018/02/quem-sao-os-conselheiroseconomicos-dos-pre-candidatos-presidencia.html>. Acessado em: 08 abr. 2018.

VALOR PRO. Disponível em: <https://www.valorpro.com.br/>. Acessado em: 08 abr. 2018.

Colunas

BARBOSA, N. Do jeito que está o texto, é melhor não aprovar a reforma trabalhista. Folha de S.Paulo, 09 jun. 2017a.

. Reforma da Previdência e eleições de 2018. Folha de S.Paulo, 10 nov. $2017 \mathrm{~b}$.

BARROS, J. R. M. de. Recuperação e sustentabilidade. O Estado de S. Paulo, 15 out. 2017.

A recuperação está aí. A sustentabilidade, não. O Estado de S. Paulo, 18 fev. 2018a.

A reforma trabalhista vai pegar. O Estado de S. Paulo, 08 jun. 2018b.

BOLLE, M. de. Explicar é preciso. O Estado de S. Paulo, 07 dez. 2016.

BOLLE, M. de. Reformas são difíceis. Estado de S. Paulo, 29 mar. 2017a. 
. Que reformas? Estado de S. Paulo, 07 jun. 2017b.

. Sai Porcina, entra Sassá. Estado de S. Paulo, 21 fev. 2018.

CARVALHO, L. Reforma da Previdência mira o passado, não o futuro. Folha de S.Paulo, 16 mar. 2017a.

. Exigir 25 anos de contribuição criará milhões de Daniel Blakes. Folha de S.Paulo, 30 mar. $2017 b$.

. Reforma trabalhista não responde aos desafios do século 21 . Folha de S.Paulo, 27 abr. 2017c.

. Reforma trabalhista pode custar caro à Previdência. Folha de S.Paulo, 02 ago. 2018a.

. PEC do teto de gastos terá de ser revista em 2019. Folha de S. Paulo, 09 ago. 2018 b.

FRANCO, G. H. B. Demônios e reformas. O Estado de S. Paulo, 26 mar. 2017a. . Reforma trabalhista: é só o começo. O Estado de S. Paulo, 30 abr. 2017 b. . Não há tempo a perder. O Estado de S. Paulo, 15 out. 2017c. . Previdência 2.0. O Estado de S. Paulo, 29 abr. 2018.

GONÇALEZ, C. A. Destino incerto para a Previdência. O Estado de S. Paulo, 19 nov. 2018.

LATIF, Z. Pensar o presente para garantir o futuro. O Estado de S. Paulo, 14 jan. 2016. . Previdência no rumo certo. O Estado de S. Paulo, 23 fev. 2017a. . Propaganda enganosa. O Estado de S. Paulo, 30 nov. 2017c. 
LISBOA, M. Roleta-russa da Previdência. Folha de S.Paulo, 17 dez. 2017 b. . Imprensa. Folha de S.Paulo, 01 abr. 2018.

NETTO, D. Aprovar a PEC 241 é urgente. Folha de S.Paulo, 21 set. 2016. . Reforma é lufada de oxigênio nas relações entre trabalho e capital. Folha de S.Paulo, 19 jul. 2017.

PASTORE, A. C. A retomada do crescimento já está à vista? O Estado de S. Paulo, 06 nov. 2016.

PASTORE, A. C. Crise política, reformas e estabilidade macroeconômica. O Estado de S. Paulo, 18 jun. 2017.

PESSÔA, S. Gastos previdenciários no Brasil são altos na comparação com OCDE. Folha de S.Paulo, 12 mar. 2017a.

PESSÔA, S. Reformas como a da Previdência são necessárias. Folha de S. Paulo, 26 mar. 2017b.

PESSÔA, S. Vamos para o reajuste? Folha de S. Paulo, 15 jul 2018.

SCHWARTSMAN, A. Sem reformas, o retorno ao crescimento fica cada vez mais distante. Folha de S.Paulo, 07 jun. 2017a. . Previdência, quatro soluções e um funeral. Folha de S.Paulo, 27 dez. $2017 b$.

Recebido em 15/08/2019. Aprovado em 31/10/2019. 